\title{
The Impacts of Servant Leadership and Organizational Politics on Burnout: A Research among Mid-Level Managers
}

\author{
Nihat Kaya ${ }^{1}$, Samet Aydin ${ }^{2} \&$ Gulumser Ongun ${ }^{1}$ \\ ${ }^{1}$ Gebze Technical University, Turkey \\ ${ }^{2}$ Maltepe University, Turkey \\ Correspondence: Samet Aydin, Maltepe University, Maltepe-İstanbul, Turkey.
}

Received: February 2, 2016

Accepted: February 15, 2016

Online Published: March 1, 2016

doi:10.5430/ijba.v7n2p26

URL: http://dx.doi.org/10.5430/ijba.v7n2p26

\begin{abstract}
Burnout, as a factor related to an individual's success, is defined as being exposed to behaviors that negatively affect performance and mainly refers to chronic stress. This research focuses on the effects of servant leadership on burnout through organizational politics. Data for the study were collected by survey method with participation of 401 employees from 49 different organizations. Obtained data were subjected to factor analysis with SPSS in order to check the internal consistency of the sample. Thereafter, by using AMOS software, confirmatory factor analysis were conducted and with structural equation modeling method research hypothesis of the study were tested. The results revealed that burnout was not emerged by servant leadership through organizational politics. Even though servant leadership is related to a change by creating a vision, this change process does not affect employees negatively because it comprises long-term plans and occurs spontaneously.
\end{abstract}

Keywords: servant leadership, organizational politics, burnout

\section{Introduction}

As in many areas, information age has led to changes in leadership styles. Today's leaders, who want their followers to perform at higher levels and collaborate to achieve company goals, serve to their followers to achieve the best. Robert K. Greenleaf defined this leadership style as "servant leadership" and highlighted that for those leaders serving to followers and organizations become a way of their life.

Servant leaders encourage their followers to generate new ideas while solving organizational problems and they place importance to collective decision-making (Stone, Russell, \& Patterson, 2004). Furthermore, servant leaders emphasize objectiveness for the benefit of employees and they put information-oriented working forward. Moreover, this leadership is related to environmental factors; for instance, in static and stable environments creating the culture of servant leadership is recommended (Smith, Montagno, \& Kuzmenko, 2004). On the other hand, there are some similarities between transformational leadership and servant leadership such as teaching effort, respect, confidence, vision, integration, and effects on followers.

The focus of the leader is the main difference between transformational leadership and servant leadership theories. Transformational leaders focus on the behaviors of employees and organizations, and they create leader-follower commitment to achieve organizational goals. On the other hand, servant leaders focus on well-being of their followers and they believe that organizational goals can only be achieved by doing this. While the focus of servant leadership is serving to followers, transformational leadership focuses on the organization that followers belong to and eventually achieving organizational goals. Servant leaders also care about individuals instead of abstract concepts and this shows that these leaders value the contents of the processes rather than the results (Stone et al., 2004).

\subsection{Servant Leadership}

Although studies regarding servant leadership were revealed first by Robert K. Greenleaf in the beginning of 19th century, the concept gained its importance in ' 90 s and created a quiet revolution in workplaces all around the world. While servant leaders increase the quality of organizational outcomes, they try to develop individuals as well (Spears, 2004). 
In addition, another characteristic of servant leadership is conceptualization that means having great dreams and looking beyond the daily realities. Likewise, "empathy", "awareness", and "focus on human development" are also among the basic characteristics of servant leadership (Spears, 2004; Stone et al. (2004). Some prior studies questioned whom is served by servant leaders and which factors make leaders as servant leaders. In these studies, "being" and "doing" attributes were determined as significant features of servant leaders and these attributes comprises the leader's self-concept and primary intent. It was stated that primary intent (doing) comprehends "serving others first, not leading" and self-concept (being) comprehends "being servant and steward, not leader or owner" (Sendjaya \& Sarros, 2002). It is possible to infer that major goals of servant leaders are to determine what their followers need and eliminate their deficiencies in order to create a powerful organization (Vinod \& Sudhakar, 2011).

\subsection{Organizational Politics}

Although being an effective concept, organizational politics has taken relatively little place in the literature until 1970s. However, later studies indicate that organizational politics should be analyzed for a better understanding of organizations (Ullah, Jafri, Gondal, \& Khyzer Bin Dost, 2011).

Recent empirical studies support that employees' ideas regarding organizational politics are better understood by focusing on perceived politics instead of applied tactics (Vigoda-Gadot \& Talmud, 2010). The concept of organizational politics can be defined from different perspectives. While it's related to the activities carried out to achieve specified targets in public institutions, in private organizations it comprises striving to achieve personal goals instead of organization's (Andrews \& Kacmar, 2001). Political struggles in organizations mostly depend on the characteristics of those organizations rather than individual differences. However, many researches put forward that situational conditions and organizational culture evoke political behaviors. For instance political behaviors can be observed when the sources of organizations diminish in time.

Some studies revealed that organizational politics prevent achieving organizational goals because it comprises functional difficulties that caused by external authorities. These external authorities benefit from conflict, power struggles, and tactical battles and they cause more complicated problems in decision-making (Ullah et al., 2011).

It can be said that political behaviors derive from mature dilemmas (Jafariania, Mortazavib, Nazemic, \& Bulld, 2012), for instance in an environment where individuals tend to achieve their own goals rather than achieving organizational goals or especially in organizations where individuality is valued (Cropanzano, Howes, Grandey, \& Toth, 1997). Therefore the structure of an organization should comply with legal and other regulations and cooperation within the organization should be ensured. In addition, organizations may become a structure formed from the impact of negative public and social sanctions in case of violation of certain regulations (Randall, Cropanzano, Bormann, \& Birjulin, 1999). The increase in these sanctions may cause an increase in fear and anxiety and also exhaustion of individuals inside organizations (Kacmar \& Baron. 1999). Furthermore, decisions made in large enterprises are often dictated by politics and participation in political decision-making is important as a matter of life and death (Ullah et al., 2011).

Previous findings showed that employees' perceived trust and social support have an important effect on the relationship between organizational politics and various job-related outcomes (job satisfaction, organizational commitment, stress, burnout etc.). In other words, if trust and social support are dominant characteristics in the organization then the negative effects of organizational politics are expected to decrease in time (Vigoda-Gadot $\&$ Talmud, 2010).

In this study Vigoda-Gadot's organizational politics scale was used and the sub-dimensions of the scale were determined as fair in pay \& promotion, fair reward and fair opinion. For sure, the deterioration in the perceptions of fairness derives from the disparity between initially perceived justice and the results (Whisenant, 2005). The term "fair pay \& promotion" means that all employees at the same level have equal pay and promotion opportunities. Similarly, "fair reward" refer to providing same rewards in terms of financial and non-financial to the individuals who perform equal. Finally, "fair opinion" states that employees are not evaluated and treated according to their ideas or opinions. The study is based on the assumption that individuals will not behave politically regarding these three conditions since those behaviors will also be restricted to external factors (Jafariani et al., 2012).

\subsection{Burnout}

The concept of burnout was first mentioned by Freudenberger (1974) and was conceptualized as an "occupational hazard". Freudenberger described burnout as "a loss of energy or power due to failure, degradation, and overload or exhaustion of individual's internal resources due to unmet demands" (as cited in Sağlam Arı \& Çına Bal, 2008). 
In recent years, the burnout concept has become a serious problem among different occupational groups thus it has drawn attention from the society. The theory suggests that burnout is a multidimensional phenomenon and previous studies revealed that burnout is a psychological response to stressful working environments and it is a result of work-related stress (Halbesleben \& Buckley, 2004). Moreover, burnout refers to a set of physical, emotional, and interactive symptoms and it is composed of emotional exhaustion, low personal accomplishment, and depersonalization. While emotional exhaustion is caused by chronic job stress, depersonalization \& negative attitudes against people are caused by frustration, mistrust, feelings of failure, low productivity, low efficiency and low effectiveness.

The results of a research on employees who work in educational services support the comments mentioned and it was found out that emotional exhaustion and low personal accomplishment significantly and negatively affect total job satisfaction. In addition, high emotional exhaustion causes a decrease in total job satisfaction and in contrast to the expectations depersonalization is not significantly related to total job satisfaction. Also, it was emphasized that there are significant relationships between burnout and total job satisfaction. Finally job satisfaction was found to be affected by burnout factors in $25 \%$ percent (Brewer \& Clippard, 2002).

\subsection{The Relationships between Servant Leadership, Burnout, and Organizational Politics}

As described previously, servant leadership behaviors like focusing on followers rather than organizational objectives may drive burnout among young employees due to the loss of confidence to reach organizational targets. Therefore, servant leaders are often criticized because they only serve to their followers and ignore taking the lead. According to some scholars, these two behaviors have a linear but opposite relationship with each other. While the first one is associated with serving others for their sake and is derived from intrinsic motivation, the second one comprises serving due to the nature of being a leader and having the idea that "I serve because I am the leader". In this leadership style it is thought that the desire to surpass others' career development efforts or personal ambitions may cause some problems (Sendjava \& Sarros. 2002). As previously mentioned, uncontrolled desires and ambitions in servant leadership can cause employees to experience burnout.

According to Russell (2001), servant leadership is based on core values and the necessity to respect others. The values of servant leadership affect not only the observed factors but also the whole organization. In this process, personal values like honesty and integrity play significant role in building trust between individuals and the organization. In this regard, it is stated that trust is a significant factor in servant leadership style for providing organizational integrity. Besides, Spears (2004) indicates that the core aim of servant leadership is building a long-term oriented transformational approach and creating a positive change in the society. In this context, it can be said that the quality of the relationship between leaders and members of the organization forms the basis of servant leadership style. In turn, burnout problems can arouse in case of a decline in the quality of this relationships. The research model is shown in Figure 1.

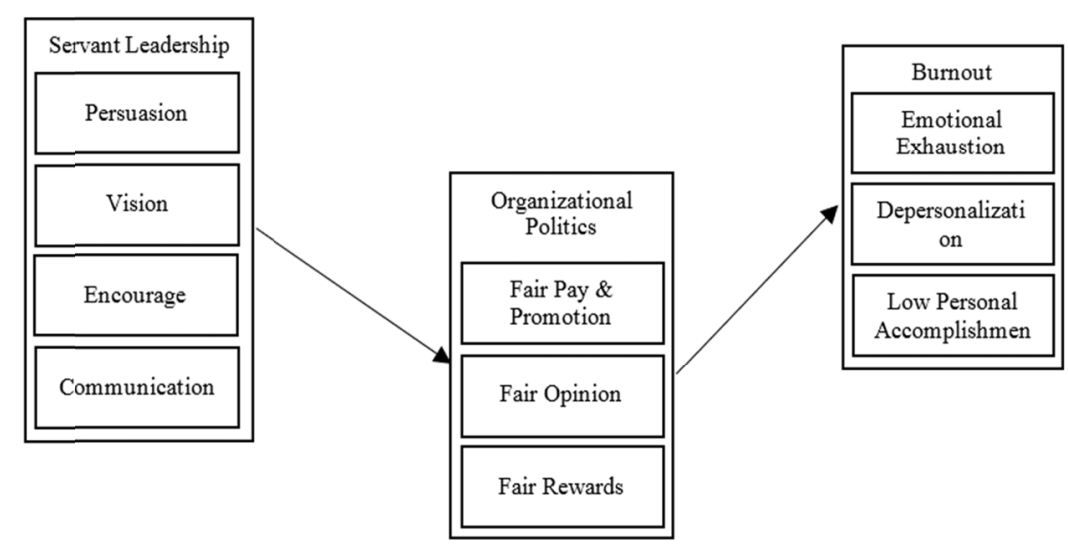

Figure 1. Research model 


\section{Method}

Relevant scales from previous studies were adapted for this study. Before moving forward, in order to prevent misunderstandings due to translation, a pilot study with a group of 40 individuals was conducted, in turn, upon their responses and comments the survey was finalized. The data for the study were collected from 401 individuals from 49 companies of diverse sectors and the participants were selected among managers who have one-to-one communication with senior management.

The data were analyzed by SPSS software. Firstly, missing data analysis were held and it was found out that missing data were very low thus they were replaced with means of each series. Secondly, after exploratory factor analysis servant leadership was divided into four dimensions including persuasion, vision, encouragement, and communication; organizational politics was evaluated in three dimensions as fair pay \& promotion, fair reward, fair opinion; and burnout were divided into three dimensions as emotional exhaustion, low personal accomplishment, and depersonalization. Finally, confirmatory factor analysis was conducted and the model fit indices were observed in desired ranges. Correlation analysis of the variables are shown in Table 1, and the results of hypothesis testing using structural equation modeling are shown in Appendix A.

Table 1. Correlation analysis

\begin{tabular}{|c|c|c|c|c|c|c|c|c|c|c|c|}
\hline & & 1 & 2 & 3 & 4 & 5 & 6 & 7 & 8 & 9 & 10 \\
\hline 1 & Persuasion & 1 & & & & & & & & & \\
\hline 2 & Vision & $.631^{* *}$ & 1 & & & & & & & & \\
\hline 3 & Encouragement & $.509^{* *}$ & $.468^{* *}$ & 1 & & & & & & & \\
\hline 4 & Communication & $.565^{* *}$ & $.594^{* *}$ & $.478^{* *}$ & 1 & & & & & & \\
\hline 5 & $\begin{array}{l}\text { Fair Pay \& } \\
\text { Promotion }\end{array}$ & $.312^{* *}$ & $.193^{* *}$ & $.270^{* *}$ & $.238^{* *}$ & 1 & & & & & \\
\hline 6 & Fair Opinion & $.438^{* *}$ & $.337^{* *}$ & $.400^{* *}$ & $.368^{* *}$ & $.415^{* *}$ & 1 & & & & \\
\hline 7 & Fairn Reward & $.561^{* *}$ & $.761^{* *}$ & $.480^{* *}$ & $.534^{* *}$ & $.239^{* *}$ & $.263^{* *}$ & 1 & & & \\
\hline 8 & $\begin{array}{l}\text { Emotional } \\
\text { Exhaustion }\end{array}$ & $-.217^{* *}$ & $-.145^{* *}$ & $-.164^{* *}$ & -.044 & $-.155^{* *}$ & $-.126^{*}$ & -.053 & 1 & & \\
\hline 9 & Depersonalization & $-.190^{* *}$ & $-.185^{* *}$ & $-.103^{*}$ & $-.143^{* *}$ & -.096 & $-.101^{*}$ & $-.144^{* *}$ & $.562^{* *}$ & 1 & \\
\hline 10 & $\begin{array}{l}\text { Low Personal } \\
\text { Achievement }\end{array}$ & $-.273^{* *}$ & $-.250^{* *}$ & $-.191^{* *}$ & $-.248^{* *}$ & $-.127^{*}$ & $-.179^{* *}$ & $-.235^{* *}$ & $.101^{*}$ & $.139^{* *}$ & 1 \\
\hline
\end{tabular}

${ }^{*} \mathrm{p}<0.05 ;{ }^{* *} \mathrm{p}<0.01$

\section{Results}

As employees' perceptions regarding their leader's persuasion and encouragement characteristics increase, their perceptions regarding the leader's fairness in organizational politics also increase thus burnout feelings is less experienced. Therefore H1a, H1b, H1c, H1d, H1e, H1f, H3a, H3b, H3c and H3d were accepted and H3e and H3f were rejected.

Despite that, relationship between leaders' visionary characteristics and fairness in organizational politics was found to be insignificant. Thus, H2a, H2c (partially), H2e, and H2f were accepted, and H2b and H2d were rejected. On the other hand, through the results it can be said that as the perception of servant leader's vision increases, burnout decreases. Another finding is that there is no significant relationship between communication capability of servant leaders and the perception of fair rewards. In addition, as servant leaders provide better communication with their followers, perceptions regarding fair pay \& promotion and fair opinion were positively affected. The insignificant relationship between communication and fair rewards could be explained by emphasizing that employees generally focus on organizational practices and they care less about temporal issues such as rewards. Thus H4a, $\mathrm{H} 4 \mathrm{~b}$, and $\mathrm{H} 4 \mathrm{c}$ were accepted.

As indicated in Appendix A, all hypotheses regarding the relationship between servant leadership and burnout were 
accepted. If all characteristics of servant leadership exists, then employee burnout will not be observed. The hypothesis which were negatively accepted show that persuasion, vision, and encouragement may play a critical role in decreasing some dimensions of burnout.

Furthermore, there was a positive relationship between communication, burnout and depersonalization but a negative relationship between communication and low personal accomplishment. On the other hand, positive results in communication dimension ( $\mathrm{H} 4 \mathrm{~d}$ and $\mathrm{H} 4 \mathrm{e}$ ) are obtained and this should be considered as one to one communication may cause depersonalization and emotional exhaustion among employees.

\section{Discussion}

The results were found to be in line with the literature and it can be said that servant leadership style may decrease burnout in general. This showed that even though servant leadership style is related to creating a vision and change, transforming process occurs spontaneously and long-term plans does not affect employees negatively. However, in previous studies it was found that short term oriented, absolute and radical changes with transformational leadership cause employee burnout. Also, negative outcomes of the change such as feeling useless, fearing to be fired and stress result burnout. Fortunately, these negative results were not observed in servant leadership and it can be said that these leaders have a better chance to decrease employee burnout.

\section{References}

Andrews, M. C., \& Kacmar, K. M. (2001). Discriminating among organizational politics, justice, and support. Journal of Organizational Behavior, 22, 347-366. http://dx.doi.org/10.1002/job.92

Brewer, E. W., \& Clippard, L. F. (2002). Burnout and job satisfaction among student support services personnel. Human Resource Development Quarterly, 13(2), 169-186. http://dx.doi.org/10.1002/hrdq.1022

Cropanzano, R., Howes, J. C., Grandey, A. A., \& Toth, P. (1997). The relationship of organizational politics and support to work behaviors, attitudes, and stress. Journal Of Organizational Behavior, 18, 159-180. http://dx.doi.org/10.1002/(SICI)1099-1379(199703)18:2<159::AID-JOB795>3.0.CO;2-D

Freudenberger, H. J. (1974). Staff Burn-Out. Journal of Social Issues, 30, 159-165. http://dx.doi.org/10.1111/j.1540-4560.1974.tb00706.x

Halbesleben, J. R. B., \& Buckley, M. R. (2004). Burnout in organizational life. Journal of Management, 30(6), 859879. http://dx.doi.org/10.1016/j.jm.2004.06.004

Jafariania, H, Mortazavib, S., Nazemic, S., \& Bulld, P. (2012). Political behavior in organizational context: Nature, research and paradigm. Management Science Letters, 2, 2987-3000. http://dx.doi.org/10.5267/j.msl.2012.09.008

Kacmar, K. M., \& Baron, R. A. (1999). Organizational politics: The state of the field, links to related processes, and an agenda for future research. Research in Personnel and Human Research Management, 17, 1-39.

Kacmar, K. M., \& Baron, R. A. (1999). Organizational politics: The state of the field, links to related processes, and an agenda for future research. In Ferris, G. R. (Ed.), Research In Personnel And Human Resources Management (Vol. 17, pp. 1-39.). Stamford, CT: JAI Press.

Randall, M. L., Cropanzano. R., Bormann. C. A., \& Birjulin. A. (1999). Organizational politics and organizational support as predictors of work attitudes, job performance, and organizational citizenship behavior. Journal of $\begin{array}{llll}\text { Organizational } & \text { Behavior, } & 20, & 159-174 .\end{array}$ http://dx.doi.org/10.1002/(SICI)1099-1379(199903)20:2<159::AID-JOB881>3.0.CO;2-7

Russell, R. F. (2001) The role of values in servant leadership. Leadership \& Organization Development Journal, 22(2), 76-83. http://dx.doi.org/10.1108/01437730110382631

Sendjaya, S. \& Sarros, J. C. (2002). Servant leadership: Its origin, development, and application in organizations. Journal of Leadership \& Organizational Studies, 9(2), 57-64. http://dx.doi.org/10.1177/107179190200900205

Smith, B. N., Montagno, R. V., \& Kuzmenko, T. N. (2004). Transformational and servant leadership: Content and contextual comparisons. Journal of Leadership and Organizational Studies, 10(4), 80-91. http://dx.doi.org/10.1177/107179190401000406

Spears, L. C. (2004). Practicing servant-leadership. Leader to Leader, 2004, 7-11. http://dx.doi.org/10.1002/lt1.94

Stone, A. G., Russell, R. F., \& Patterson, K. (2004). Transformational versus servant leadership: A difference in leader focus. The Leadership \& Organization Development Journal, 25(4), 349-361. 
http://dx.doi.org/10.1108/01437730410538671

Ullah, S., Jafri, A. R., Gondal, M. A., \& Khyzer Bin Dost, M. (2011). The dark side of employee behavior: An explanation of factors instigating organizational politics. African Journal of Business Management, 5(26), 10428-10433. http://dx.doi.org/10.5897/AJBM11.1057

Vigoda-Gadot, E., \& Talmud, I. (2010). Organizational politics and job outcomes: The moderating effect of trust and social support. Journal of Applied Social Psychology, 40(11), 2829-2861. http://dx.doi.org/10.1111/j.1559-1816.2010.00683.x

Vinod, S., \& Sudhakar, B. (2011). Servant leadership: A unique art of leadership. Interdisciplinary Journal of Contemporary Research in Business, 2(11), 456-467.

Whisenant, W. (2005). Organizational justice and commitment in interscholastic sports. Sport, Education and Society, 10(3), 343-357. http://dx.doi.org/10.1080/13573320500155041

\section{Appendix A}

\begin{tabular}{|c|c|c|c|c|c|}
\hline Hypothesis & Servant Leadership & $\begin{array}{l}\text { Organizational Politics } \\
\text { Servant Leadership }\end{array}$ & $\boldsymbol{\beta}$ & $\mathbf{P}$ & Result \\
\hline $\mathrm{H}_{1 \mathrm{a}}$ & $\begin{array}{l}\text { Servant Leadership - } \\
\text { Persuasion }\end{array}$ & $\begin{array}{l}\text { Organizational Politics - Fair } \\
\text { Pay \& Promotion }\end{array}$ & 0.282 & 0.000 & Accepted(+) \\
\hline $\mathrm{H}_{1 \mathrm{~b}}$ & & $\begin{array}{l}\text { Organizational Politics - Fair } \\
\text { Opinion }\end{array}$ & 0.300 & 0.000 & Accepted(+) \\
\hline $\mathrm{H}_{1 \mathrm{c}}$ & & $\begin{array}{l}\text { Organizational Politics - Fair } \\
\text { Rewards }\end{array}$ & 0.255 & 0.000 & Accepted(+) \\
\hline $\mathrm{H}_{1 \mathrm{~d}}$ & & $\begin{array}{l}\text { Burnout }-\quad \text { Emotional } \\
\text { Exhaustion }\end{array}$ & -0.425 & 0.000 & Accepted(-) \\
\hline $\mathrm{H}_{1 \mathrm{e}}$ & & Burnout - Depersonalization & -0.128 & 0.002 & Accepted(-) \\
\hline $\mathrm{H}_{1 \mathrm{f}}$ & & $\begin{array}{l}\text { Burnout }- \text { Low Personal } \\
\text { Accomplishment }\end{array}$ & -0.120 & 0.097 & $\begin{array}{l}\text { Partially } \\
\text { Accepted(-) }\end{array}$ \\
\hline $\mathrm{H}_{2 \mathrm{a}}$ & $\begin{array}{l}\text { Servant Leadership - } \\
\text { Vision }\end{array}$ & $\begin{array}{l}\text { Organizational Politics - Fair } \\
\text { Pay \& Promotion }\end{array}$ & -0.116 & 0.024 & Accepted(-) \\
\hline $\mathrm{H}_{2 b}$ & & $\begin{array}{l}\text { Organizational Politics - Fair } \\
\text { Opinion }\end{array}$ & -0.071 & 0.159 & Rejected \\
\hline $\mathrm{H}_{2 \mathrm{c}}$ & & $\begin{array}{l}\text { Organizational Politics - Fair } \\
\text { Rewards }\end{array}$ & -0.134 & 0.087 & $\begin{array}{l}\text { Partially } \\
\text { Accepted(-) }\end{array}$ \\
\hline $\mathrm{H}_{2 \mathrm{~d}}$ & & $\begin{array}{l}\text { Burnout } \quad-\quad \text { Emotional } \\
\text { Exhaustion }\end{array}$ & -0.052 & 0.496 & Rejected \\
\hline $\mathrm{H}_{2 \mathrm{e}}$ & & Burnout - Depersonalization & -0.061 & 0.098 & $\begin{array}{l}\text { Partially } \\
\text { Accepted(-) }\end{array}$ \\
\hline $\mathrm{H}_{2 \mathrm{f}}$ & & $\begin{array}{l}\text { Burnout }- \text { Low Personal } \\
\text { Accomplishment }\end{array}$ & -0.135 & 0.055 & $\begin{array}{l}\text { Partially } \\
\text { Accepted(-) }\end{array}$ \\
\hline $\mathrm{H}_{3 \mathrm{a}}$ & $\begin{array}{l}\text { Servant Leadership - } \\
\text { Encouragement }\end{array}$ & $\begin{array}{l}\text { Organizational Politics - Fair } \\
\text { Pay \& Promotion }\end{array}$ & 0.209 & 0.000 & Accepted $(+)$ \\
\hline $\mathrm{H}_{3 \mathrm{~b}}$ & & $\begin{array}{l}\text { Organizational Politics - Fair } \\
\text { Opinion }\end{array}$ & 0.343 & 0.000 & Accepted $(+)$ \\
\hline $\mathrm{H}_{3 \mathrm{c}}$ & & $\begin{array}{l}\text { Organizational Politics - Fair } \\
\text { Rewards }\end{array}$ & 0.594 & 0.000 & Accepted(+) \\
\hline $\mathrm{H}_{3 \mathrm{~d}}$ & & Burnout $\quad-\quad$ Emotional & -0.170 & 0.043 & Accepted(-) \\
\hline
\end{tabular}




\begin{tabular}{|c|c|c|c|c|c|}
\hline \multirow[b]{2}{*}{$\mathrm{H}_{3 \mathrm{e}}$} & & \multicolumn{4}{|l|}{ Exhaustion } \\
\hline & & Burnout - Depersonalization & 0.003 & 0.947 & Rejected \\
\hline $\mathrm{H}_{3 \mathrm{f}}$ & & $\begin{array}{l}\text { Burnout }- \text { Low Personal } \\
\text { Accomplishment }\end{array}$ & -0.036 & 0.639 & Rejected \\
\hline $\mathrm{H}_{4 \mathrm{a}}$ & $\begin{array}{l}\text { Servant Leadership - } \\
\text { Communication }\end{array}$ & $\begin{array}{l}\text { Organizational Politics - Fair } \\
\text { Pay \& Promotion }\end{array}$ & 0.111 & 0.058 & $\begin{array}{l}\text { Partially } \\
\text { Accepted(+) }\end{array}$ \\
\hline $\mathrm{H}_{4 \mathrm{~b}}$ & & $\begin{array}{l}\text { Organizational Politics - Fair } \\
\text { Opinion }\end{array}$ & 0.121 & 0.018 & Accepted(+) \\
\hline $\mathrm{H}_{4 \mathrm{c}}$ & & $\begin{array}{l}\text { Organizational Politics - Fair } \\
\text { Rewards }\end{array}$ & -0.136 & 0.082 & $\begin{array}{l}\text { Partially } \\
\text { Accepted(-) }\end{array}$ \\
\hline $\mathrm{H}_{4 \mathrm{~d}}$ & & $\begin{array}{l}\text { Burnout }- \\
\text { Exhaustion }\end{array}$ & 0.351 & 0.000 & Accepted(+) \\
\hline $\mathrm{H}_{4 \mathrm{e}}$ & & Burnout - Depersonalization & 0.075 & 0.045 & Accepted(+) \\
\hline $\mathrm{H}_{4 \mathrm{f}}$ & & $\begin{array}{l}\text { Burnout - Low Personal } \\
\text { Accomplishment }\end{array}$ & -0.154 & 0.030 & $\begin{array}{l}\text { Partially } \\
\text { Accepted(-) }\end{array}$ \\
\hline
\end{tabular}

Results of Regression Analysis 